\title{
ACTH stimulates insulin secretion from MIN6 cells and primary mouse and human islets of Langerhans
}

\author{
H T Al-Majed, P M Jones, S J Persaud, D Sugden, G C Huang', \\ S Amiel ${ }^{\mathbf{1}}$ and $\mathbf{B}$ J Whitehouse
}

Centre for Reproduction, Endocrinology and Diabetes, GKT School of Biomedical Sciences, King's College London, Guy's Campus, London SE1 1UL, UK

${ }^{1}$ Diabetes, Endocrinology and Internal Medicine, GKT School of Medicine, Denmark Hill, London SE5 9PJ, UK

(Requests for offprints should be addressed to B J Whitehouse; Email: barbara.whitehouse@kcl.ac.uk)

\begin{abstract}
It has previously been suggested that ACTH and ACTHrelated peptides may act as paracrine modulators of insulin secretion in the islets of Langerhans. We have, therefore, examined the expression and function of the ACTH receptor (the melanocortin 2 receptor, MC2-R) in human and mouse primary islet tissue and in the MIN6 mouse insulinoma cell line. Mouse MC2-R mRNA was detected in both MIN6 cells and mouse islet tissue by PCR amplification of cDNA. In perifusion experiments with MIN6 pseudo-islets, a small, transient increase in insulin secretion was obtained when $\mathrm{ACTH}_{1-24}(1 \mathrm{nM})$ was added to medium containing $2 \mathrm{mM}$ glucose (control) but not when the medium glucose content was increased to $8 \mathrm{mM}$. Further investigations were performed using static incubations of MIN6 cell monolayers; $\mathrm{ACTH}_{1-24}$ (1 pM$10 \mathrm{nM}$ ) provoked a concentration-dependent increase in insulin secretion from MIN6 monolayer cells that achieved statistical significance at concentrations of 1 and $10 \mathrm{nM} \quad(150 \pm 13 \cdot 6 \% \quad$ basal secretion; $187 \pm 14 \cdot 9 \%$ basal secretion, $P<0 \cdot 01)$. Similar responses were obtained with $\mathrm{ACTH}_{1-39}$. The phosphodiesterase inhibitor IBMX $(100 \mu \mathrm{M})$ potentiated the responses to sub-maximal doses of $\mathrm{ACTH}_{1-24}$. Two inhibitors of the protein kinase A (PKA) signaling pathway, Rp-cAMPS $(500 \mu \mathrm{M})$ and
\end{abstract}

H-89 $(10 \mu \mathrm{M})$, abolished the insulin secretory response to $\mathrm{ACTH}_{1-24}(0 \cdot 5-10 \mathrm{nM})$. Treatment with $1 \mathrm{nM}$ $\mathrm{ACTH}_{1-24}$ caused a small, statistically significant increase in intracellular cAMP levels. Secretory responses of MIN6 cells to $\mathrm{ACTH}_{1-24}$ were also influenced by changes in extracellular $\mathrm{Ca}^{2+}$ levels. Incubation in $\mathrm{Ca}^{2+}$-free buffer supplemented with $0.1 \mathrm{mM}$ EGTA blocked the MIN6 cells' secretory response to 1 and $10 \mathrm{nM} \mathrm{ACTH}$ A-24 $_{1}$. Similar results were obtained when a $\mathrm{Ca}^{2+}$ channel blocker (nitrendipine, $10 \mu \mathrm{M}$ ) was added to the $\mathrm{Ca}^{2+}$ containing buffer.

$\mathrm{ACTH}_{1-24}$ also evoked an insulin secretory response from primary tissues. The addition of $\mathrm{ACTH}_{1-24}(0 \cdot 5 \mathrm{nM})$ to perifusions of mouse islets induced a transient increase in insulin secretion at $8 \mathrm{mM}$ glucose. Perifused human primary islets also showed a secretory response to $\mathrm{ACTH}_{1-24}$ at basal glucose concentration $(2 \mathrm{mM})$ with a rapid initial spike in insulin secretion followed by a decline to basal levels. Overall the results demonstrate that the MC2-R is expressed in $\beta$-cells and suggest that activation of the receptor by ACTH initiates insulin secretion through the activation of PKA in association with $\mathrm{Ca}^{2+}$ influx into $\beta$-cells.

Journal of Endocrinology (2004) 180, 155-166

\section{Introduction}

It has been known for many years that adrenocorticotropin (ACTH) not only plays an essential role in the control of the adrenal cortex but that it also influences a number of tissues outside the gland including the central nervous system, adipose tissue and skin (see Hadley \& HaskellLuevano 1999, Solomon 1999). Following reports that treatment with ACTH caused hypoglycemia it was suggested that the endocrine pancreas might also be a target (Lebovitz et al. 1965, 1966). This view gained further support from the demonstration that ACTH directly stimulated insulin secretion by pancreatic preparations from a range of animals including rats, mice, rabbits and toads ( Lebovitz \& Pooler 1967, Malaisse et al. 1967, Sussman \& Vaughan 1967, Curry \& Bennet 1973, Flores et al. 1998). More recent studies have confirmed that exogenous ACTH also enhances the secretion of insulin by isolated rat islets of Langerhans (Borelli et al. 1994, 1996, Gagliardino et al. 1995, 1997).

The physiological effects of ACTH in the adrenal cortex are mediated through the melanocortin 2 receptor (MC2-R) which is expressed at high levels in the gland and coupled to the cAMP/protein kinase A (PKA) signal transduction system (Mountjoy et al. 1992, Vinson et al. 1992, Xia \& Wikberg 1996). In agreement with this, early 
studies of the effects of ACTH on $\beta$-cells suggested the involvement of cAMP, although these generally used non-physiological concentrations of ACTH (Malaisse et al. 1967, Sussman \& Vaughan 1967, Kuo et al. 1973). More recently intracellular $\mathrm{Ca}^{2+}$ has been identified as a key regulator of insulin secretion (see Ashcroft \& Ashcroft 1992) and changes in intracellular $\mathrm{Ca}^{2+}$ have also been implicated in the stimulatory effects of ACTH on insulin secretion from mouse $\beta$-cells (Gronda et al. 1992, Gagliardino et al. 1995, 1997).

In the present study we have examined the expression and function of the MC2-R in primary islets and an insulin-secreting $\beta$-cell line to determine whether physiologically relevant concentrations of ACTH can influence $\beta$-cell function, and to identify the intracellular transduction mechanism involved. We demonstrate that the MC2-R is expressed in $\beta$-cells and that activation of the receptor by ACTH initiates insulin secretion through the activation of PKA in association with $\mathrm{Ca}^{2+}$ influx into the $\beta$-cells.

\section{Materials and Methods}

\section{Materials}

MIN6 cells were kindly provided by Professor J I Miyazaki (University of Osaka, Japan). PCR primer preparation and DNA sequencing was performed by the Molecular Biology Unit, King's College London, UK. Connaught Medical Research Laboratory (CMRL) medium, fetal calf serum (FCS), glutamine, penicillin/streptomycin and Superscript II reverse transcriptase were obtained from Gibco (Paisley, UK). Taq DNA polymerase was purchased from Promega, RNAzol B from Biogenesis (Poole, UK), Rp-cAMPS (adenosine- $3^{\prime}, 5^{\prime}$-cyclic monophosphorothioate) from BIOLOG (Bremen, Germany) and H-89 from Calbiochem (Nottingham, UK). ACTH A $_{1-24}$ (tetracosactrin acetate; Synacthen) was supplied by Alliance Pharmaceticals, Chippenham, UK). All other biochemicals were obtained from Sigma.

\section{Maintenance of MIN6 cells and pseudoislets}

MIN6 cells were maintained at $37{ }^{\circ} \mathrm{C}\left(95 \% \mathrm{O}_{2} / 5 \% \mathrm{CO}_{2}\right)$ in Dulbecco's modified Eagle's medium (DMEM) supplemented with 15\% FCS, $2 \mathrm{mM}$ glutamine and $100 \mathrm{U} / \mathrm{ml}$ penicillin $/ 0 \cdot 1 \mathrm{mg} / \mathrm{ml}$ streptomycin. Medium was changed every 3-4 days and monolayer cells were detached from the tissue culture plastic using a $0.02 \%$ EDTA solution when $80-90 \%$ confluent. MIN6 pseudoislets were cultured under the same conditions as monolayers but in tissue culture flasks pre-coated with gelatin $(1 \% \mathrm{w} / \mathrm{v})$. All experiments using pseudoislets were carried out 6-8 days after subculturing of the MIN6 cells.

\section{Isolation of human and mouse islets}

Mouse islets of Langerhans were prepared by collagenase digestion of the pancreas in vitro, and purified by hand-picking under a dissecting microscope, as described previously (Roderigo-Milne et al. 2002). Human islets were obtained through the Dixon's Human Islet Project at King's College Hospital. Pancreata were retrieved, with permission, from non-diabetic, heart-beating organ donors and islets were isolated under aseptic conditions according to the method of London et al. (1990, 1998). Islets were used after maintenance overnight in CMRL medium supplemented with $15 \%$ FCS and $100 \mathrm{U} / \mathrm{ml}$ penicillin/ $0.1 \mathrm{mg} / \mathrm{ml}$ streptomycin.

\section{Insulin secretion}

For static incubation experiments, MIN6 monolayer cells were seeded into $96-$ well plates at a density of 30000 cells/well and cultured for 2 days in DMEM at $37^{\circ} \mathrm{C}$. The cells were pre-incubated in glucose-free DMEM for $2 \mathrm{~h}$ prior to the start of experiments. The cells were subsequently washed with a bicarbonate-buffered physiological salt solution, Gey \& Gey buffer (Gey \& Gey

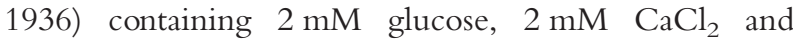
$0.5 \mathrm{mg} / \mathrm{ml} \mathrm{BSA}$, and incubated for $1 \mathrm{~h}$ in the salt solution supplemented with agents of interest. The insulin content of the incubation medium was assessed using an in-house radioimmunoassay with an antibody to bovine insulin generated in guinea pigs (Jones et al. 1988).

Perifusion experiments were used for measurement of the dynamics of the secretory response. MIN6 pseudoislets were pre-incubated for $2 \mathrm{~h}$ in glucose-free DMEM after which equal aliquots of pseudoislets were transferred to perifusion chambers $(\sim 1000$ pseudoislets per chamber $)$ essentially as described for primary rat islets (Jones et al. 1989, Persaud et al. 2002). Pseudoislets exist as freefloating structures on the gelatin substrate, and can be removed and placed in the perifusion chambers by simple pipetting, eliminating any element of dispersal in their preparation for perifusion. In this respect they are handled in the same way as primary islets of Langerhans, and like primary islets they maintain their structure during the perifusion. Human and mouse islets were treated in a similar fashion, and approximately 100 primary islets were used per perifusion chamber because of the higher insulin content of primary tissue compared with MIN6 cells (Hauge-Evans et al. 1999). Tissues were perifused for $1 \mathrm{~h}$ $\left(0.5 \mathrm{ml} / \mathrm{min}, 37^{\circ} \mathrm{C}\right)$ with Gey \& Gey buffer containing $2 \mathrm{mM}$ glucose to ensure a stable baseline rate of insulin secretion, after which fractions were collected at 2 min intervals and agents of interest were added to the perifusate, as described below.

\section{Detection of ACTH receptor by RT-PCR}

Total RNA was isolated from MIN6 cells, mouse brain and mouse and rat adrenal cortex cells using a commercially available kit, RNAzol B. RNA $(1-5 \mu \mathrm{g})$ was transcribed into cDNA using oligo $(\mathrm{dT})_{18}$ primers, random 


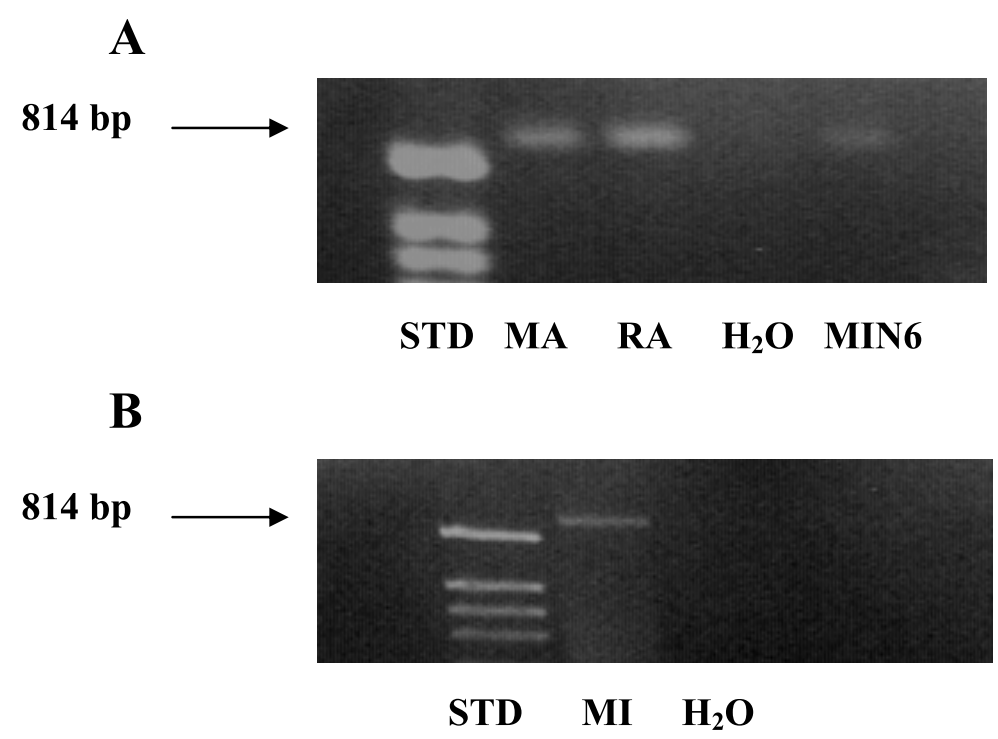

Figure 1 Detection of MC2-R (ACTH receptor) by PCR. Products obtained from RT-PCR amplification are shown after separation by gel electrophoresis. (A) The lanes containing products amplified from cDNA from mouse adrenal (MA), rat adrenal (RA) and MIN6 cells all exhibit a PCR product with a molecular weight corresponding to the expected $814 \mathrm{bp}$ fragment of MC2-R. Rat and mouse adrenal tissues were used as positive controls, water $\left(\mathrm{H}_{2} \mathrm{O}\right)$ as negative control. (B) The lane containing mouse islets (MI) exhibits a similar sized fragment. Lane 1 (STD) shows molecular weight markers.

10-mer primers and Superscript II reverse transcriptase. PCR was performed using $0.5 \mu \mathrm{M}$ primers and $1 \mu \mathrm{l}$ cDNA in a standard reaction mixture containing $100 \mu \mathrm{M}$ dNTPs, $1 \times$ PCR buffer and 1 unit Taq DNA polymerase added in hot start conditions. The MC2-R cDNA was amplified using oligonucleotide primers designed to amplify a $814 \mathrm{bp}$ product specific for mouse MC2-R. The forward and reverse primer sequences were $5^{\prime}$ AAC TCC GAT TGT CCT GAT GTA G 3' and 5' CTT TTG AAT GCA TCT CTG AGC TC 3' respectively (Boston \& Cone 1996). PCR was performed using a final concentration of $0.5 \mu \mathrm{M}$ of both forward and reverse primers in a standard reaction mixture. Forty cycles of amplification were performed in the presence of $0.5 \mathrm{mM} \mathrm{MgCl}_{2}$ under the following conditions: melting $95^{\circ} \mathrm{C}$ for $1 \mathrm{~min}$, annealing $57^{\circ} \mathrm{C}$ for $1 \mathrm{~min}$, extension $72{ }^{\circ} \mathrm{C}$ for $1 \mathrm{~min}$. PCR products were separated on a $1.5 \%$ agarose gel and visualized by ethidium bromide staining. After separation, the PCR products were eluted from the agarose, purified using a QIAquick Gel Extraction Kit and sequenced to confirm their identity (Molecular Biology Unit, King's College London, UK).

\section{cAMP assay}

MIN6 monolayers were incubated for $1 \mathrm{~h}$ with Gey \& Gey containing $2 \mathrm{mM}$ glucose at $37{ }^{\circ} \mathrm{C}, 5 \% \mathrm{CO}_{2}$, followed by non-tryptic dispersal into cell suspensions to avoid damage to cell surface receptors. Cells were counted, and 50000 cells were resuspended in $400 \mu$ pre-warmed $\left(37^{\circ} \mathrm{C}\right)$ Gey \& Gey buffer containing $100 \mu \mathrm{M}$ isobutylmethylxanthine (IBMX) in the presence or absence of $\mathrm{ACTH}_{1-24}(0 \cdot 1,1,10 \mathrm{nM})$ or $10 \mu \mathrm{M}$ forskolin (FSK) and incubated for $20 \mathrm{~min}$ at $37^{\circ} \mathrm{C}$. After centrifugation to pellet the cells, $100 \mu$ l of the incubation medium was added to $400 \mu \mathrm{l}$ borate buffer for assay of insulin content. The remainder of the supernatant was discarded and $250 \mu \mathrm{l}$ ice-cold $50 \mathrm{mM} \mathrm{Na}$ acetate $(\mathrm{pH} \mathrm{6.2)} \mathrm{was} \mathrm{added} \mathrm{to}$ the cell pellet. Samples were then boiled, sonicated and stored at $-20{ }^{\circ} \mathrm{C}$ until assayed for cAMP content using the method of Harper \& Brooker (1975) with acetylation.

\section{Results}

Detection of MC2-R expression in MIN6 cells and mouse islets

MIN6 cells expressed RNA species that could be amplified using specific PCR primers for the MC2-R as shown in Fig. 1A. The product amplified from MIN6 cDNA was similar to the product amplified from total RNA extracted from mouse adrenal (MA) and rat adrenal (RA) tissues, which were used as positive controls and the molecular weight of the products corresponded to the expected DNA fragment of $814 \mathrm{bp}$. A similar product was amplified from mouse islet cDNA (MI), as shown in Fig. 1B. DNA 
sequencing confirmed that the PCR fragments derived from the mouse islets and MIN6 cells contained the predicted regions of the MC2-R (data not shown).

Effect of $A C T H_{1-24}$ on insulin secretion from MIN6 cells and pseudoislets

ACTH $_{1-24}$ stimulated insulin secretion both from MIN6 pseudoislets in perifusions and from monolayers of MIN6 cells in static incubations. Figures $2 \mathrm{~A}$ and $\mathrm{B}$ show the effect of 1 and $10 \mathrm{nM} \mathrm{ACTH}$ A-24 $_{14}$, respectively, on insulin release from MIN6 pseudoislets that were perifused with buffer containing $2 \mathrm{mM}$ glucose for $10 \mathrm{~min}$ before addition of $\mathrm{ACTH}_{1-24}$. It can be seen that $1 \mathrm{nM}$ $\mathrm{ACTH}_{1-24}$ evoked a significant increase in insulin secretion $(186 \pm 13 \%$ basal, $P<0 \cdot 01)$, a further enhancement of the secretory response was observed when MIN6 pseudoislets were perifused with $10 \mathrm{nM} \mathrm{ACTH}_{1-24}$ with a peak rise to $235 \pm 11 \%$ basal secretion $(P<0 \cdot 01$, vs $1 \mathrm{nM}$ $\left.\mathrm{ACTH}_{1-24}\right)$. The responses were characterized by an initial elevation that reached peak values within 5-6 min of the onset of stimulation and then declined to basal levels after 10-12 min, despite the continued presence of $\mathrm{ACTH}_{1-24}$. Increasing the glucose content of the medium to $8 \mathrm{mM}$ caused a rapid and marked increase in insulin secretion from perifused MIN6 pseudoislets (Fig. 2C) with a typical, transient first phase peak $(249 \pm 15 \%)$ that is followed by a sustained second phase of secretion at a significantly lower level $(165 \pm 15 \%, P<0 \cdot 01)$. When $\mathrm{ACTH}_{1-24}(1 \mathrm{nM}$ or $10 \mathrm{nM}$; Figs 2D and E) was added to the perifusion medium in the second phase of secretion, there was an elevation of insulin secretion to levels that were not significantly different from those achieved in the first phase.

The effects of $\mathrm{ACTH}_{1-24}$ and $\mathrm{ACTH}_{1-39}$ on insulin secretion by monolayers of MIN6 cells were tested in static incubation experiments over a 20-minute period. Figure $3 \mathrm{~A}$ indicates that $\mathrm{ACTH}_{1-24}(1 \mathrm{pM}-10 \mathrm{nM})$ provoked a concentration-dependent increase in insulin secretion from MIN6 monolayer cells that achieved statistical significance at a concentration of $0 \cdot 1 \mathrm{nM}$. Similar responses were obtained with $\mathrm{ACTH}_{1-39}$ (0.1 nM-10 nM, Fig. 3B).

\section{Effect of ACTH on $\beta$ cell cAMP}

To determine whether ACTH activated adenylate cyclase in MIN6 cells, intracellular cAMP levels were determined following treatment with FSK $(10 \mu \mathrm{M})$ or $\mathrm{ACTH}_{1-24}$ $(0 \cdot 1 \mathrm{nM}$ and $1 \mathrm{nM})$. Cells were incubated in buffer containing $2 \mathrm{mM}$ glucose and supplemented with IBMX $(100 \mu \mathrm{M})$ for $20 \mathrm{~min}$ in the absence or presence of stimulants (Table 1). Addition of FSK $(10 \mu \mathrm{M})$ to the incubation medium evoked a large increase in cAMP levels in MIN6 $(P<0 \cdot 01)$. Addition of $0 \cdot 1 \mathrm{nM} \mathrm{ACTH}_{1-24}$ had no effect on cAMP levels but $1 \mathrm{nM} \mathrm{ACTH}{ }_{1-24}$ caused a small, statistically significant increase $(P<0 \cdot 05)$.

\section{Effect of IBMX on the response to ACTH}

The phosphodiesterase inhibitor, IBMX $(100 \mu \mathrm{M})$, potentiated the response of MIN6 cells to sub-maximal doses of $\mathrm{ACTH}_{1-24}$, as shown in Fig. 4. A dose-related stimulation of insulin secretion was obtained in the presence of $\mathrm{ACTH}_{1-24}$ with a significant potentiation of the response by IBMX being detected at concentrations between $0 \cdot 1$ and $5 \mathrm{nM}$. Similar results were obtained when cells were exposed to $\mathrm{ACTH}_{1-39}$ in the presence of IBMX (data not shown).

\section{Effect of PKA inhibitors on the response to ACTH}

The effects of two structurally dissimilar agents that inhibit PKA, Rp-cAMPS $(500 \mu \mathrm{M})$ and $\mathrm{H}-89(10 \mu \mathrm{M})$, were studied. Figures $5 \mathrm{~A}$ and $\mathrm{B}$ show that the concentrationdependent stimulation of insulin secretion by $\mathrm{ACTH}_{1-24}$ $(0 \cdot 5-10 \mathrm{nM}$, open bars) was abolished in the presence of either PKA inhibitor.

\section{Importance of extracellular $\mathrm{Ca}^{2+}$ in the response to $\mathrm{ACTH}$}

Secretory responses of MIN6 cells to $\mathrm{ACTH}_{1-24}$ were influenced by changes in extracellular $\mathrm{Ca}^{2+}$ levels. MIN6 monolayers were incubated for $20 \mathrm{~min}$ with $\mathrm{ACTH}_{1-24}$ (1 and $10 \mathrm{nM}$ ), in the absence or presence of $2 \mathrm{mM} \mathrm{CaCl}_{2}$ in the incubation medium (Fig. 6). As shown above, insulin release was significantly increased by $\mathrm{ACTH}_{1-24}$ when MIN6 cells were incubated in the presence of extracellular $\mathrm{Ca}^{2+}$. However, incubation with $\mathrm{ACTH}_{1-24}$ had no effect on insulin secretion in a $\mathrm{Ca}^{2+}$-free buffer supplemented with $0.1 \mathrm{mM}$ EGTA, and the addition of a blocker of L-type voltage-gated $\mathrm{Ca} 2+$ channels (nitrendipine, $10 \mu \mathrm{M}$ ) to the $\mathrm{Ca}^{2+}$-containing buffer also blocked the secretory response to 1 and $10 \mathrm{nM}$ $\mathrm{ACTH}_{1-24}$.

Effects of $\mathrm{ACTH}_{1-24}$ on insulin secretion from primary tissue

$\mathrm{ACTH}_{1-24}$ evoked an insulin secretory response from perifused mouse islets (Fig. 7). The islets were perifused with buffer containing $2 \mathrm{mM}$ glucose for $10 \mathrm{~min}$ followed by perifusion with buffer supplemented with $8 \mathrm{mM}$ glucose alone for $20 \mathrm{~min}$, then followed by $0 \cdot 5,1$ and $5 \mathrm{nM}$ $\mathrm{ACTH}_{1-24}$ for $10 \mathrm{~min}$ each in the presence of $8 \mathrm{mM}$ glucose. Insulin release from perifused mouse islets in response to $8 \mathrm{mM}$ glucose was characterized by an initial rapid peak between 2 and 3 min followed by a decline to a sustained plateau above the basal levels after 10-12 min. The addition of $0.5 \mathrm{nM} \mathrm{ACTH}{ }_{1-24}$ induced a small and transient increase in insulin secretion from mouse islets at 
A

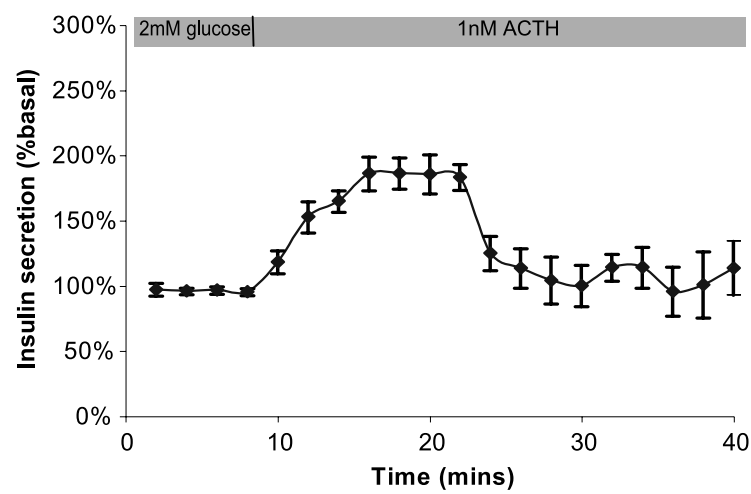

C

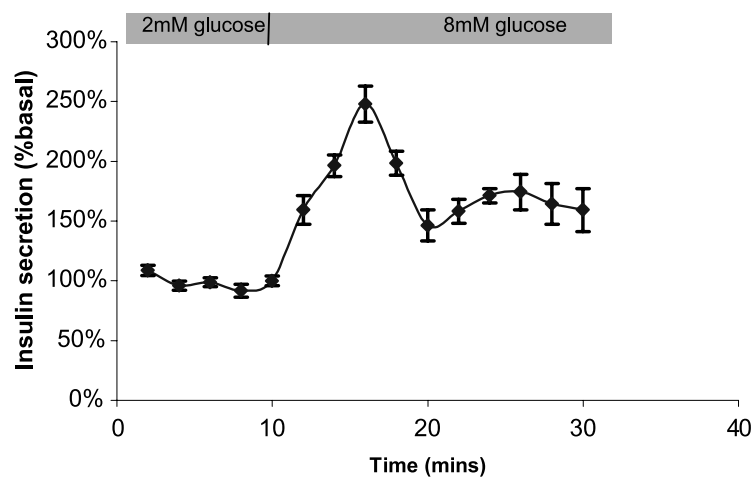

$\mathbf{E}$

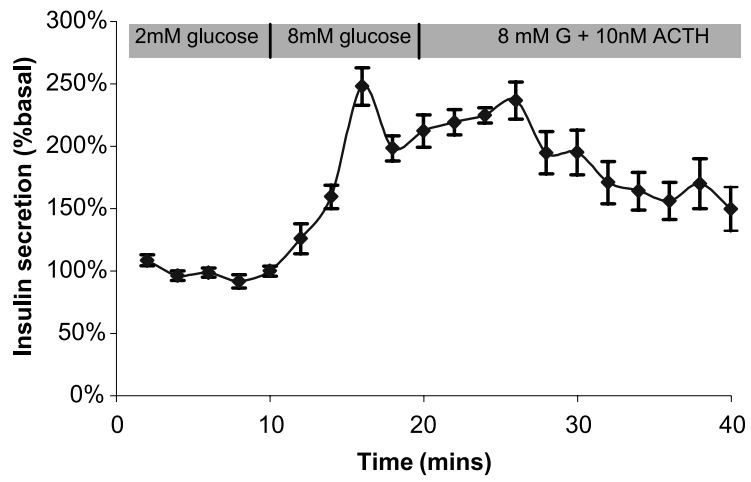

B

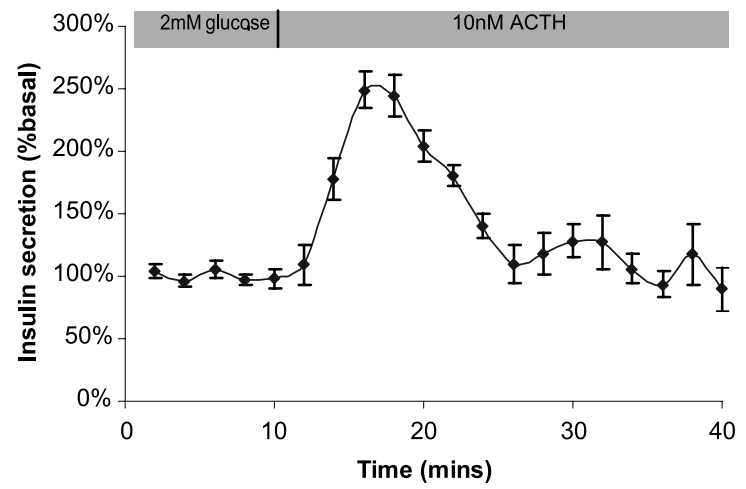

D

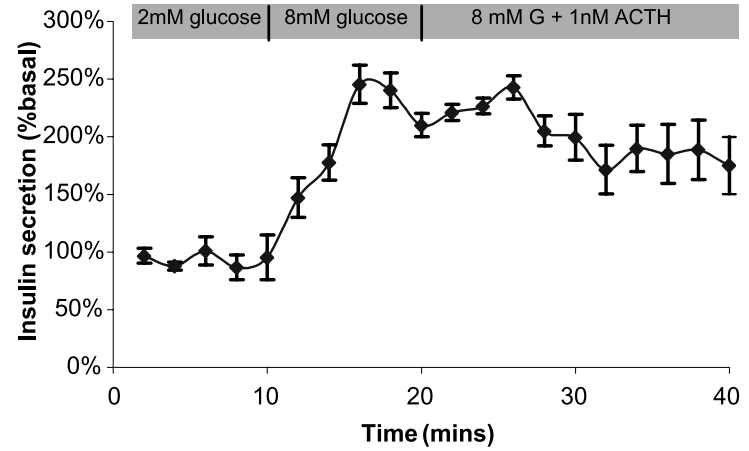

Figure 2 Effect of $\mathrm{ACTH}_{1-24}$ on insulin secretion by perifused MIN6 pseudoislets at basal and stimulatory glucose concentrations. MIN6 pseudoislets were perifused with buffer containing $2 \mathrm{mM}$ glucose for 10 min before stimulation: (A) $1 \mathrm{nM}$ and (B) $10 \mathrm{nM} \mathrm{ACTH}_{1-24}$ for $30 \mathrm{~min}$; (C) application of buffer containing $8 \mathrm{mM}$ glucose for $20 \mathrm{~min}$ and (D, E) application of medium containing $8 \mathrm{mM}$ glucose for $10 \mathrm{~min}$ before stimulation with $8 \mathrm{mM}$ glucose $(\mathrm{G})$ and $1 \mathrm{nM}(\mathrm{D})$ and $10 \mathrm{nM}$ (E) $\mathrm{ACTH}_{1-24}$ for 20 min. Responses were expressed as percentage of basal insulin secretion in the absence of $\mathrm{ACTH}_{1-24}$. Bars showed means \pm S.E.M., $n=4$ channels for each treatment.

$8 \mathrm{mM}$ glucose. The presence of higher concentrations of $\mathrm{ACTH}_{1-24}(1$ and $5 \mathrm{nM})$ in the perifusion medium caused further transient increases in secretion but these were smaller than the initial response.
Figure 8 demonstrates that human primary islets also showed significant secretory responses to $\mathrm{ACTH}_{1-24}$ at both sub-stimulatory and stimulatory concentrations of glucose. Human islets were perifused with buffer 
A

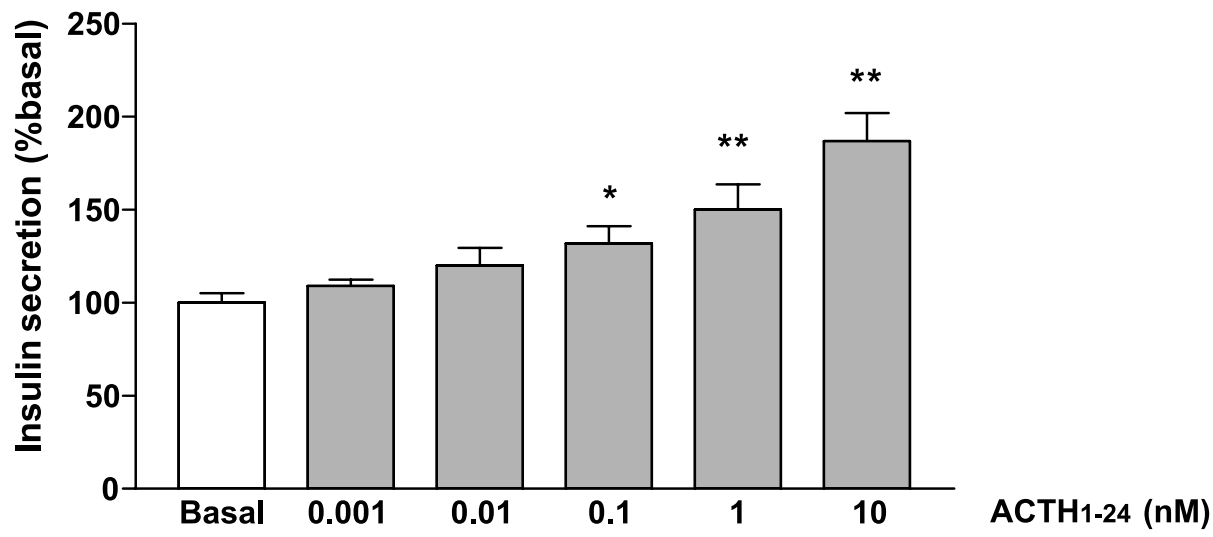

B

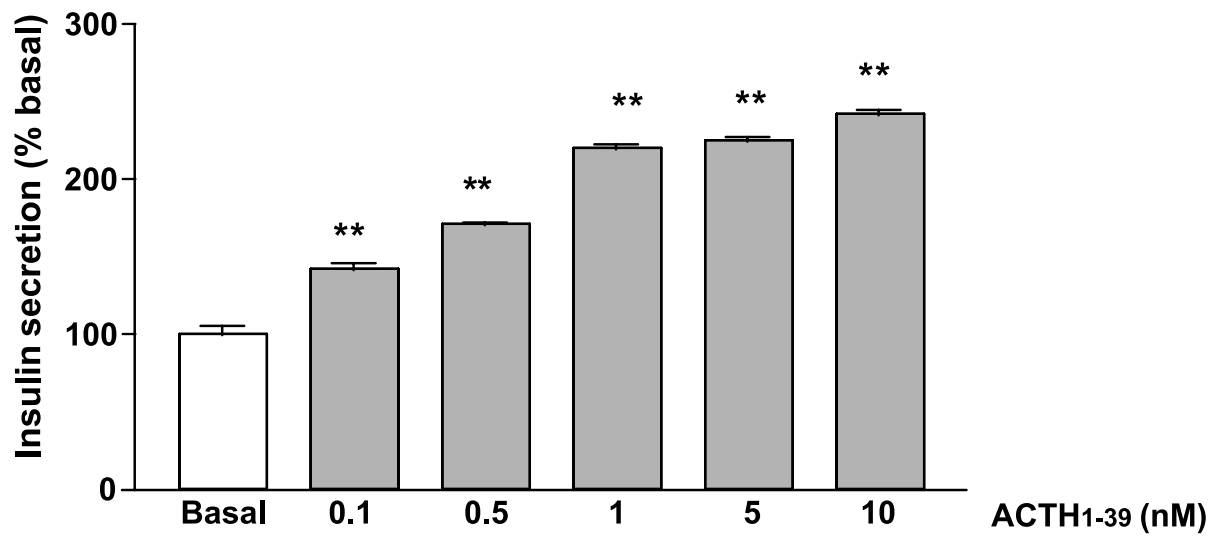

Figure 3 Effects of $\mathrm{ACTH}_{1-24}$ and $\mathrm{ACTH}_{1-39}$ on insulin secretion by MIN6 cells. MIN6 cells were incubated for $20 \mathrm{~min}$ in buffer containing $2 \mathrm{mM}$ glucose in the presence or absence of $(\mathrm{A}) \mathrm{ACTH}_{1-24}(0 \cdot 001-10 \mathrm{nM})$ or (B) $\mathrm{ACTH}_{1-39}(0 \cdot 1-10 \mathrm{nM})$. The secretory responses were expressed as a percentage of basal secretion (A, $0.589 \mathrm{ng} / 30000$ cells/hr; B, 0.851 ng/30 000 cells/hr). Bars represent means \pm S.E.M., $n=8$ observations, ${ }^{* *} P<0.01$ vs basal secretion, ${ }^{*} P<0.05$ vs basal secretion.

containing $2 \mathrm{mM}$ glucose for $10 \mathrm{~min}$ before stimulation with $1 \mathrm{nM} \mathrm{ACTH}$ A $_{14}$ for $20 \mathrm{~min}$ followed by $5 \mathrm{nM}$ $\mathrm{ACTH}_{1-24}$ for a similar period. At basal glucose concentration $(2 \mathrm{mM})$, the ACTH-mediated secretory response was direct and rapid in onset $(2-3 \mathrm{~min})$. The response was characterized by an initial increase in insulin secretion to $319 \pm 12 \cdot 9 \%$ of basal secretion followed by a decline to basal levels. A subsequent exposure to $5 \mathrm{nM} \mathrm{ACTH} \mathrm{Al}_{1-24}$ did not affect insulin release as markedly, although a slight, transient increase was observed. The response to $1 \mathrm{nM}$ $\mathrm{ACTH}_{1-24}$ was also measured at $8 \mathrm{mM}$ glucose, as shown in Fig. 8B. As expected, the stimulatory glucose concentration induced a marked increase in insulin secretion from human islets and $1 \mathrm{nM} \mathrm{ACTH}{ }_{1-24}$ caused a further transient increase in insulin secretion when added in the presence of the stimulatory glucose concentration.

\section{Discussion}

The results obtained in the present study confirm and extend previous reports of a direct insulinotropic action of pro-opiomelanocortin (POMC)-related peptides by demonstrating that $\mathrm{ACTH}$ increases insulin release from both mouse and human primary islet tissue and also from MIN6 cells, a pure $\beta$-cell line. Our experiments suggest that the effect of ACTH on insulin secretion from $\beta$-cells is mediated through the MC2-R, that it is dependent on activation of PKA, and that it requires $\mathrm{Ca}^{2+}$ entry into the $\beta$-cells through voltage dependent $\mathrm{Ca}^{2+}$ channels.

The results obtained show that pancreatic $\beta$-cells express the MC2-R. RT-PCR confirmed the expression of the MC2-R mRNA in mouse islets and the detection of the same mRNA in MIN6 cells suggest that the 
Table 1 Effects of FSK and ACTH on intracellular cAMP content of MIN6 cells. MIN6 cells were incubated for $20 \mathrm{~min}$ in buffer containing $100 \mu \mathrm{M}$ IBMX (control) in the presence of $0 \cdot 1$ or $1 \mathrm{nM}$ $\mathrm{ACTH}_{1-24}$ or $10 \mu \mathrm{M}$ FSK. After centrifugation, the cAMP content of the cell lysate was measured by RIA

\section{CAMP}

(fmol/20 000 cells/30 min

\section{Treatment}

$100 \mu \mathrm{M}$ IBMX

$100 \mu \mathrm{M}$ IBMX+10 $\mu \mathrm{M}$ FSK

$100 \mu \mathrm{M}$ IBMX+0.1 nM ACTH ${ }_{1-24}$

$100 \mu \mathrm{M} \mathrm{IBMX}+1 \mathrm{nM} \mathrm{ACTH} \mathrm{A}_{1-24}$

$74 \cdot 7 \pm 2 \cdot 8$

$233 \cdot 3 \pm 8 \cdot 1^{* *}$

$81 \cdot 7 \pm 3 \cdot 8$

$102 \cdot 6 \pm 7 \cdot 7^{*}$

${ }^{*} * P<0 \cdot 01,{ }^{*} P<0 \cdot 05$

expression occurs in the $\beta$-cells of islets of Langerhans. Sequencing of the PCR products confirmed the identity of the predicted regions of the MC2-R. This is the first demonstration of the MC2-R in $\beta$-cells, its distribution was initially found to be restricted to the adrenal cortex (Mountjoy et al. 1992). Since then ACTH receptors have also been found in low abundance in skin, adipose tissue and, most recently, in fetal testis (Boston \& Cone 1996, Slominski et al. 1996, O'Shaugnessy et al. 2003). Pharmacological studies have indicated that the MC2-R binds ACTH with much higher affinity than other melanocortin-derived peptides (Schioth et al. 1996), suggesting that this receptor is responsible for mediating the effects of ACTH in $\beta$-cells.

We have shown that ACTH consistently increased insulin release from MIN6 cells in both perifusions and static incubations at a sub-stimulatory glucose concentration. To ensure that this effect represented a true initiation of a secretory response, rather than the amplifi- cation of a glucose-induced secretory response (see Ashcroft \& Ashcroft 1992), in these experiments the basal glucose concentration was maintained at $2 \mathrm{mM}$, well below the threshold at which glucose will initiate a secretory response (4-5 mM; Ashcroft \& Ashcroft 1992). The naturally occurring hormone, $\mathrm{ACTH}_{1-39}$, and a synthetic peptide with full corticotropic activity, ACTH $_{1-24}$ (Baumann et al. 1986), were similarly effective as insulin secretagogues in static incubations over doses ranging from $100 \mathrm{pM}$ to $10 \mathrm{nM}$. In perifusion experiments using MIN6 cells configured as pseudoislets, the response to 1 and $10 \mathrm{nM} \mathrm{ACTH}$ at $2 \mathrm{mM}$ glucose was characterized by a rapid increase in insulin secretion that returned to almost basal levels within $15 \mathrm{~min}$ in the continued presence of the peptide. The transience of the response to ACTH is not entirely unexpected since the relatively rapid desensitization of $\beta$-cell responses to other receptoroperated stimuli has been reported previously (e.g. Squires et al. 1994, Kesper et al. 1999). This rapid desensitization could also explain the much reduced secretory responses to a second exposure to ACTH that was observed in the present study. A similar progressive decline in insulin secretory responses to repetitive cholinergic activation has been attributed to changes in protein kinase $\mathrm{C}$ activation (Verspohl \& Wienecke 1998). The responses to ACTH, although still detectable, were partially masked by the marked secretory response to stimulatory concentrations of glucose $(8 \mathrm{mM})$ in the perfusions. Previously, it was generally maintained that receptor-operated insulinotropic stimuli do not initiate insulin secretion, but instead act to enhance the magnitude of secretory responses initiated by nutrients such as glucose (see Ashcroft \& Ashcroft 1992, Jones \& Persaud 1998). However, our data clearly demonstrate that ACTH can initiate insulin secretion from MIN6 cells and human primary islets at sub-stimulatory

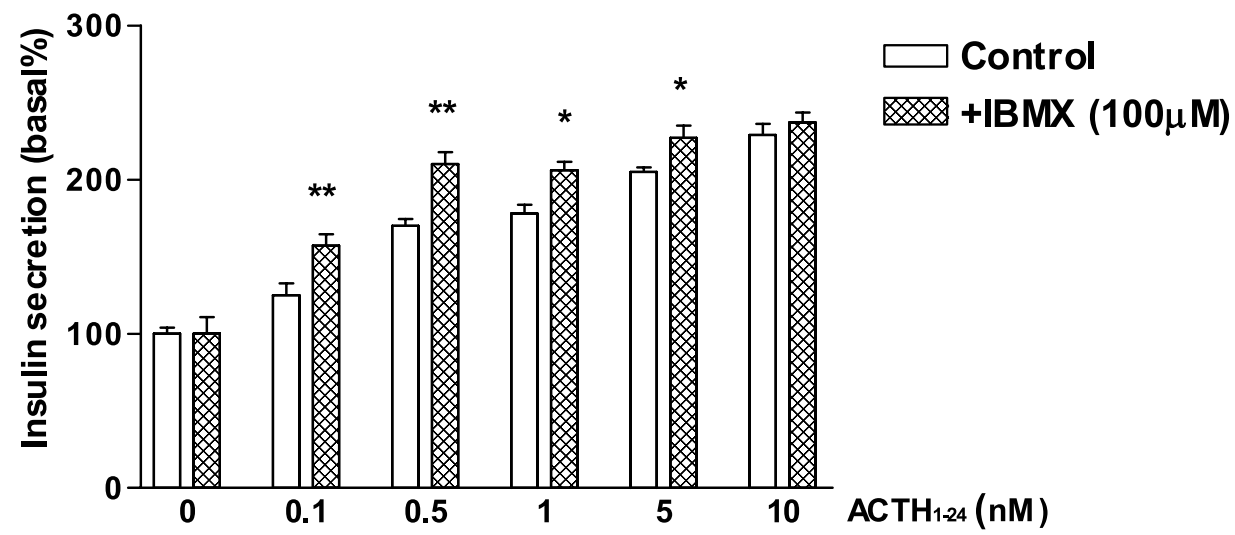

Figure 4 The effect of IBMX on the response of MIN6 cells to $\mathrm{ACTH}_{1-24}$. The cells were incubated for $20 \mathrm{~min}$ in buffer containing $2 \mathrm{mM}$ glucose in the absence or presence of $\mathrm{ACTH}_{1-24}(0 \cdot 1-50 \mathrm{nM})$ alone or $\mathrm{ACTH}_{1-24}+100 \mu \mathrm{M}$ IBMX. Data are expressed as percentage of basal secretion: $0.657 \mathrm{ng} / 30000$ cells/hr. Bars represent means \pm S.E.M. of eight observations. IBMX caused a significant potentiation of $\mathrm{ACTH}_{1-24}$-induced insulin secretion at all concentrations of $\mathrm{ACTH}_{1-24}$. ${ }^{*} P<0.05$ vs no IBMX, ${ }^{*} P<0.01$ vs no IBMX. 

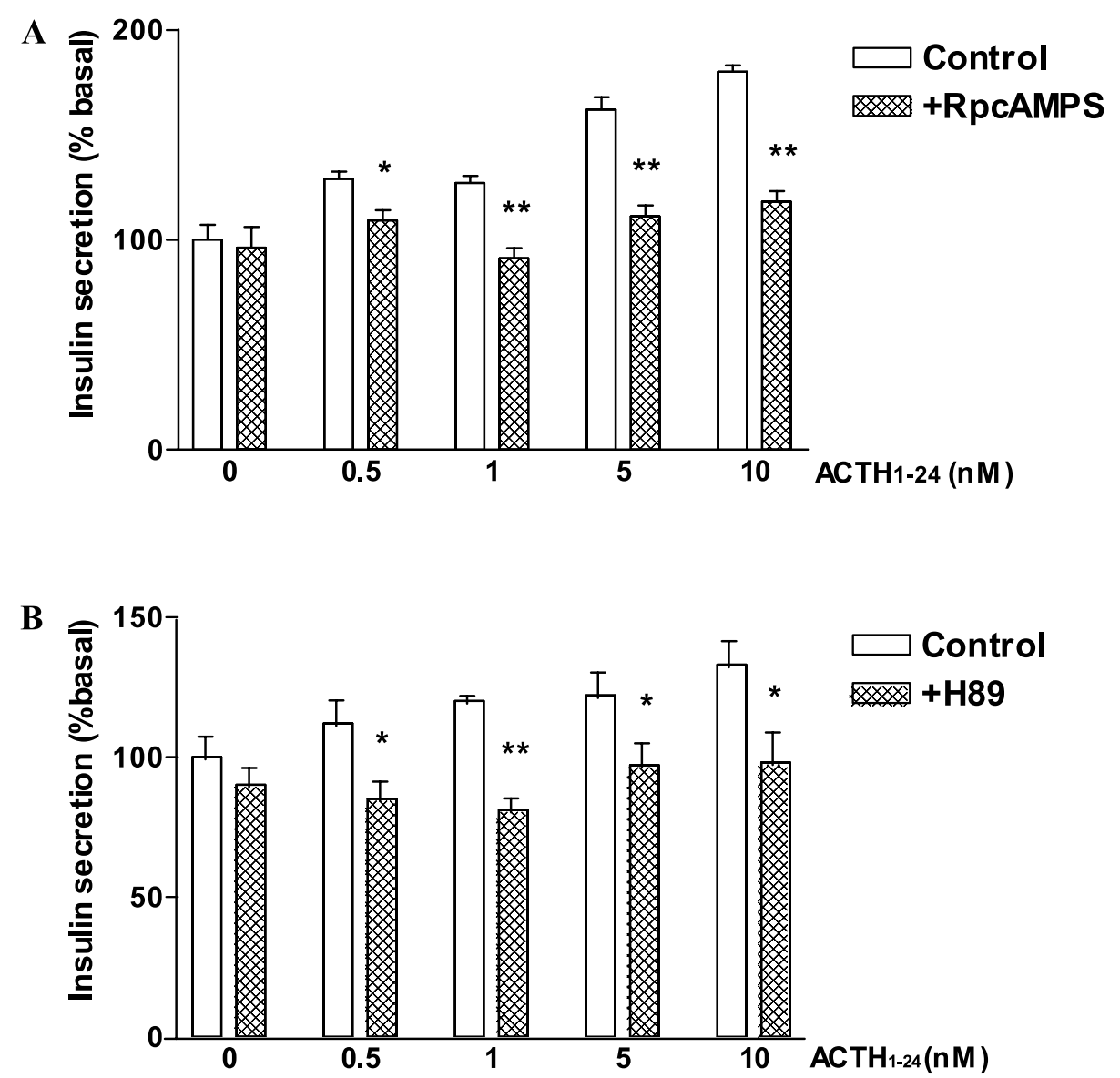

Figure 5 Effect of Rp-cAMPS and $\mathrm{H}-89$ on the response of MIN6 cells to $\mathrm{ACTH}_{1-24}$. The cells were incubated with $\mathrm{ACTH}_{1-24}$ for $20 \mathrm{~min}(\mathrm{~A})$ in the presence or absence of the competitive inhibitor Rp-cAMPS $(500 \mu \mathrm{M})$ or $(\mathrm{B})$ after pretreatment with $\mathrm{H}-89(10 \mu \mathrm{M})$. Responses were expressed as percentage of basal secretion (A, 0.983 ng/30 000 cells/hr, B, 0.976 ng/30 000 cells/hr). Bars represent means \pm S.E.M. of eight observations. Both Rp-cAMPS and $\mathrm{H}-89$ inhibited the secretory responses to $0 \cdot 5,1,5$ and $10 \mathrm{nM} \mathrm{ACTH}_{1-24} \cdot{ }^{* *} P<0 \cdot 01,{ }^{*} P<0 \cdot 05$ vs appropriate $\mathrm{ACTH}_{1-24}$ concentrations.

concentrations of glucose. This capacity of ACTH to initiate insulin secretion was also observed in studies with rat islets of Langerhans where exogenous $\mathrm{ACTH}_{1-39}$ initiated insulin secretion at a sub-stimulatory glucose concentration (Gronda et al. 1992, Borelli et al. 1994, 1996, Gagliardino et al. 1997). However, in this case ACTH was also found to potentiate glucose-induced $(16.7 \mathrm{mM})$ insulin secretion to a marked extent. Insulin secretion from primary $\beta$-cells in islets is modulated by a complex system of endocrine and paracrine signals. Thus, responses in whole pancreas and islet preparations may involve interactions between different cell types that cannot occur in homogeneous $\beta$-cell preparations (Pipeleers 1987). Our use of MIN6 cells configured as monolayers and pseudoislets has demonstrated a direct stimulatory action of ACTH on $\beta$-cells and provided a model system in which to investigate the mode of action of $\mathrm{ACTH}$ in the absence of paracrine influences.
It has long been known that the ACTH action in the adrenal cortex is coupled to activation of the cAMPdependent PKA signaling pathway (Garren et al. 1971, Vinson et al. 1992). Early studies with pancreatic preparations implicated cAMP in the effects of ACTH on insulin secretion (Malaisse et al. 1967, Sussman \& Vaughan 1967, Kuo et al. 1973) and the data obtained from the present experiments with MIN6 cells also support this model. First, measurement of the cAMP content of MIN6 cells revealed increased cAMP following stimulation by $\mathrm{ACTH}_{1-24}$. Secondly, the phosphodiesterase inhibitor, IBMX, significantly potentiated ACTH-induced insulin release at sub-maximal ACTH concentrations, consistent with the view that ACTH and IBMX are both working by increasing levels of cAMP. Thirdly, the role of PKA in ACTH-induced insulin secretion was confirmed by the use of two structurally and functionally dissimilar PKA inhibitors. Rp-cAMPS is an 


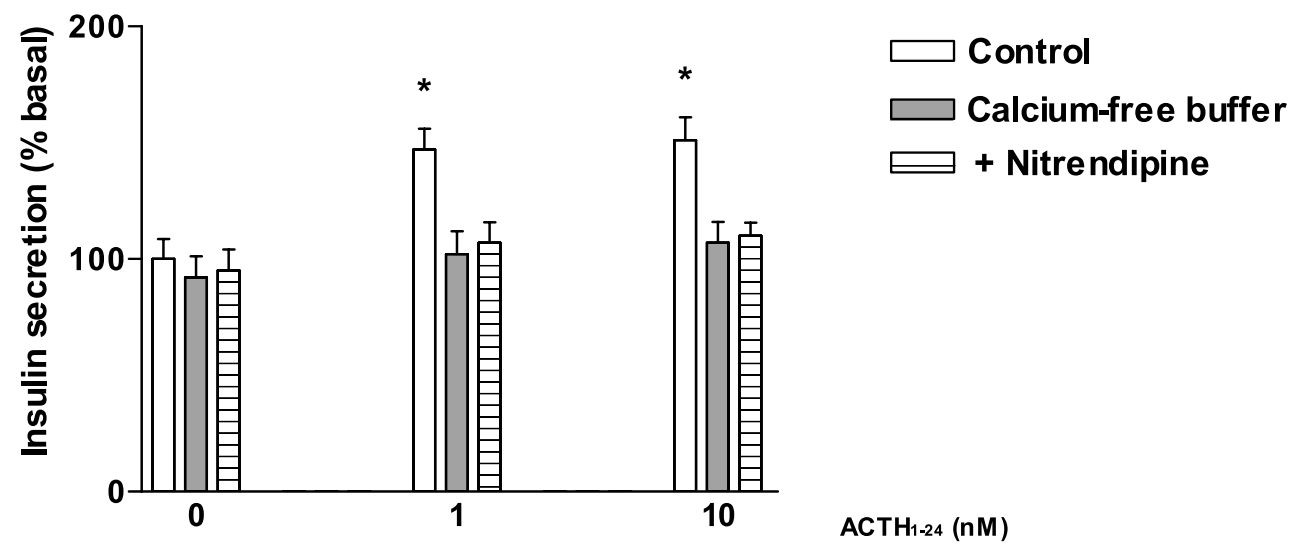

Figure 6 Effect of extracellular $\mathrm{Ca}^{2+}$ levels on the response of MIN6 monolayer cells to $\mathrm{ACTH}_{1-24}$. The cells were incubated for 20 mins with 1 or $10 \mathrm{nM} \mathrm{ACTH}_{1-24}$ either in normal (control) or $\mathrm{Ca}^{2+}$-free buffer, or in the presence of the $\mathrm{Ca}^{2+}$ channel blocker, nitrendipine $(10 \mu \mathrm{M})$. The responses were expressed as percentage of basal secretion $(0.872 \mathrm{ng} / 30000$ cells/hr). Bars represent means \pm S.E.M. of nine observations in two experiments. There was a significant increase in insulin secretion in response to $\mathrm{ACTH}_{1-24}$ in the presence of extracellular $\mathrm{Ca}^{2+}$ but not in its absence from the incubation medium or in the presence of nitrendipine. ${ }^{*} P<0 \cdot 01$ vs no ACTH.

inhibitor which competes with cAMP in binding to the regulatory subunit of PKA (Botelho et al. 1988, Persaud et al. 1990), while H-89 binds to the ATP-binding site of the PKA catalytic subunit (Chijiwa et al. 1990). Both compounds inhibited the insulin secretory response of MIN6 cells to a range of concentrations of ACTH, implicating PKA activation as a major player in transducing the effects of ACTH on insulin secretion.

Agents that increase intracellular cAMP in pancreatic $\beta$-cells are generally thought to enhance insulin release at

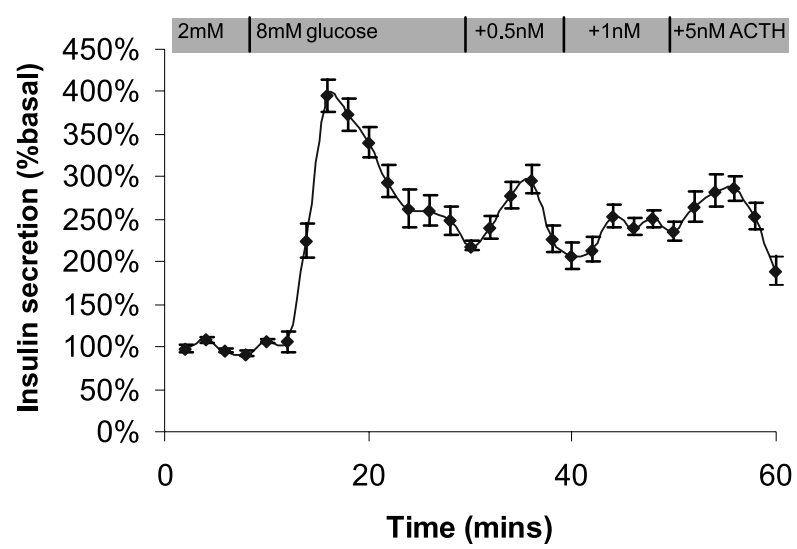

Figure 7 Effect of $\mathrm{ACTH}_{1-24}$ on insulin secretion by perifused mouse islets. After perifusion for $1 \mathrm{~h}$ with Gey \& Gey buffer containing $2 \mathrm{mM}$ glucose to equilibrate insulin secretion, mouse islets were then perifused for $10 \mathrm{~min}$ with $2 \mathrm{mM}$ glucose medium before application of $8 \mathrm{mM}$ glucose medium for $20 \mathrm{~min}$. This was followed by perifusion with increasing concentrations of $\mathrm{ACTH}_{1-24}$ $(0 \cdot 5,1$ and $5 \mathrm{nM})$ for $10 \mathrm{~min}$ each in the continued presence of $8 \mathrm{mM}$ glucose. Responses were expressed as percentage of basal insulin secretion in the absence of $\mathrm{ACTH}_{1-24}$. Bars showed means \pm S.E.M., $n=4$ channels for each treatment. stimulatory, but not at sub-stimulatory, glucose levels (reviewed by Hughes \& Ashcroft 1992). However, the present study suggests that ACTH can initiate an insulin secretory response at a sub-stimulatory concentration of glucose, perhaps by activating other intracellular pathways in parallel with the PKA pathway. It has been suggested that ACTH may modulate glucose-induced insulin secretion through pathways coupled to increased cytosolic $\mathrm{Ca}^{2+}$ (Gronda et al. 1992, Gagliardino et al. 1997) and recent studies in the $\beta T C 3$ and MIN6 cell lines have demonstrated PKA-dependent modulation of $\mathrm{Ca}^{2+}$ entry through L-type $\mathrm{Ca}^{2+}$ channels (Gao et al. 2002, Gomez et al. 2002). Our studies support a role for $\mathrm{Ca}^{2+}$ entry in ACTHinduced insulin secretion since secretory responses were blocked by the absence of extracellular $\mathrm{Ca}^{2+}$ and by the presence of nitrendipine, an L-type voltage-dependent $\mathrm{Ca}^{2+}$ channel blocker. These results imply that $\mathrm{Ca}^{2+}$ movement from the extracellular space into $\beta$-cells is required for $\mathrm{ACTH}$-induced insulin secretion, although the secretory response is primarily PKA-dependent. It seems plausible that ACTH receptor activation will influence the function of $\beta$-cells and adrenal cells using similar intracellular transduction systems. Our observations in $\beta$-cells are consistent with reports of ACTH action in the adrenal cortex suggesting that stimulation of steroid synthesis by ACTH, although primarily PKA-mediated, also appears to involve a requirement for uptake of extracellular $\mathrm{Ca}^{2+}$ (Kojima et al. 1985a,b, Schiebinger et al. 1986, Gallo-Payet \& Payet 1989). Thus, removal of extracellular $\mathrm{Ca}^{2+}$ blocked the steroidogenic effects of ACTH on bovine adrenocortical cells, while the addition of $\mathrm{Ca}^{2+}$ restored normal cortisol synthesis (Davies et al. 1985). In the present study we were unable to show any ACTHinduced changes in intracellular $\mathrm{Ca}^{2+}$ in MIN6 cells by 
A

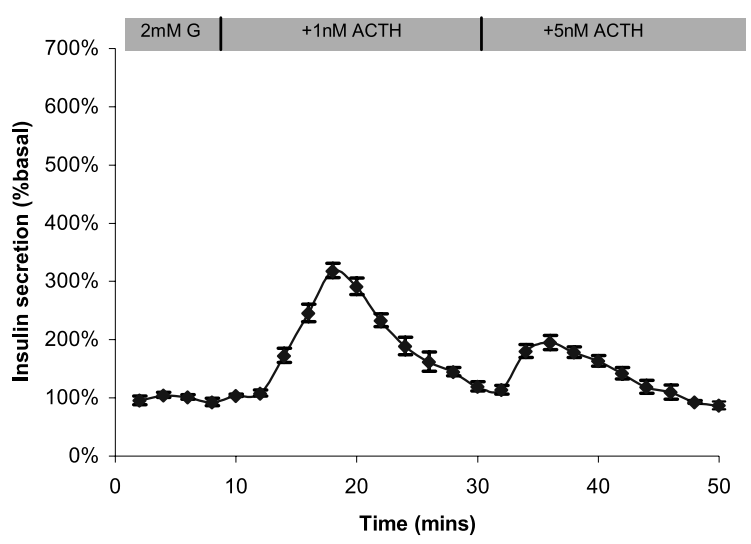

B

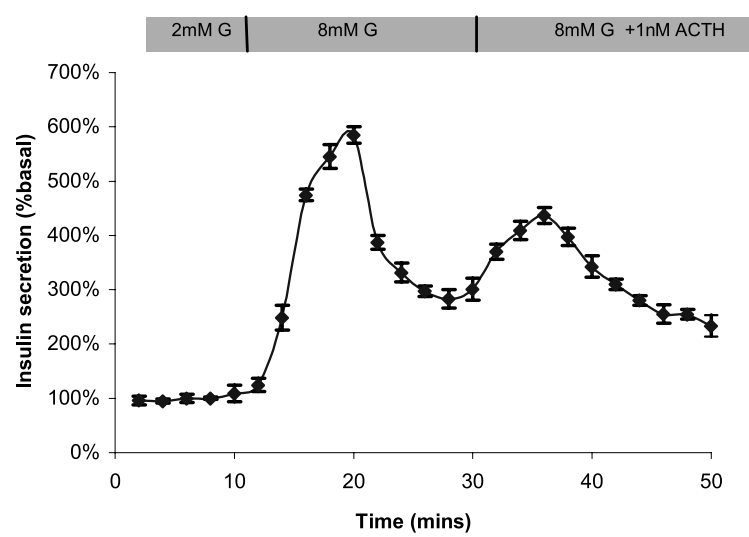

Figure 8 Effects of $\mathrm{ACTH}_{1-24}$ on insulin secretion by human primary islets. Human islets were perifused for $1 \mathrm{~h}$ with Gey \& Gey buffer containing $2 \mathrm{mM}$ glucose $(\mathrm{G})$. This was followed by (A) perifusion with medium containing $2 \mathrm{mM} \mathrm{G}$ supplemented with 1 and then $5 \mathrm{nM} \mathrm{ACTH}{ }_{1-24}$ for 20 min each, or (B) perifusion with $8 \mathrm{mM} \mathrm{G}$ medium for 20 min followed by perifusion with $8 \mathrm{mM} \mathrm{G}$ and $1 \mathrm{nM} \mathrm{ACTH}{ }_{1-24}$ for $20 \mathrm{~min}$. Secretory responses were expressed as percentage of basal secretion. Bars showed means \pm S.E.M., $n=4$ channels for each treatment.

Fura-2 microfluorimetry (data not shown), but this does not rule out a role for ACTH-induced $\mathrm{Ca}^{2+}$ entry into the cells. Thus, in adrenocortical cells, ACTH caused changes in permeability to $\mathrm{K}^{+}$that led to $\mathrm{Ca}^{2+}$ influx through voltage-dependent $\mathrm{Ca}^{2+}$ channels. However, this influx of extracellular $\mathrm{Ca}^{2+}$ did not produce sustained increases in intracellular $\mathrm{Ca}^{2+}$, suggesting that ACTH caused an increased flux of $\mathrm{Ca}^{2+}$ through the cell (Kenyon et al. 1985).

Our experiments using mouse and human islets demonstrate that the ability to respond to $\mathrm{ACTH}$ is a property of primary $\beta$-cells, suggesting that $\mathrm{ACTH}$ receptor activation may play a physiological role in regulating $\beta$-cell function. The lowest effective concentration of ACTH $(100 \mathrm{pM})$ in our experiments was somewhat higher than the normal circulating concentration of this peptide (1$10 \mathrm{pM}$; Estivariz et al. 1988). However, there are circumstances under which pancreatic $\beta$-cells may be exposed to considerably higher concentrations of ACTH and/or related peptides, for example through local release. It is known that peptides within the pancreas can influence insulin secretion, for example VIP (vasoactive intestinal peptide) and GRP (gastrin releasing peptide) have been localized in nerve terminals within islets and their prime function appears to be to stimulate insulin secretion upon parasympathetic activation (Ahren 2000). It has also been suggested that ACTH or ACTH-like peptides may be similarly involved in the fine control of insulin release; immunoreactive $\mathrm{ACTH}$ has been detected within the pancreas and shown to be released from rat islets after glucose stimulation (Larsson 1978, Sanchez-Franco et al. 1981, Borelli et al. 1994, 1996, Putti et al. 1999). In addition, there are diseases, such as ACTH-dependent Cushing's syndrome or congenital adrenal hyperplasia, where concentrations of ACTH in the plasma may be sufficient to affect insulin secretion (Newell-Price et al. 1998, Merke et al. 2002). However, in both conditions glucocorticoid levels, whether endogenous or exogenous, are also likely to be raised (Charmandari et al. 2002). It is difficult, therefore, to assess the contribution ACTH might make to disease pathology against this background, given the known effects of glucocorticoids on insulin secretion and action (Vinson et al. 1992).

In conclusion, our studies suggest that ACTH and related peptides can influence $\beta$-cell function through activation of the MC2-R, leading to the activation of PKA and increased $\mathrm{Ca}^{2+}$ entry through voltage dependent $\mathrm{Ca}^{2+}$ channels. The physiological relevance of these effects is most likely to be in the fine control of $\beta$-cell function, in a system where ACTH acts along with other biologically active peptides that are released from peptidergic neurons terminating within the islets of Langerhans.

\section{Funding}

H T A Majed was funded by a PhD scholarship from the government of Kuwait. The human islet isolation was supported by a research grant from Dixons Charitable Trust, UK.

\section{References}

Ahren B 2000 Autonomic regulation of islet hormone secretion-implications for health and disease. Diabetologia 43 393-410.

Ashcroft FM \& Ashcroft SJH 1992 Mechanism of insulin secretion. In Insulin. Molecular Biology to Pathology, pp. 97-150. Eds FM Ashcroft \& SJH Ashcroft. Oxford: Oxford University Press.

Baumann JB, Eberle AN, Christen E, Ruch W \& Girard J 1986 Steroidogenic activity of highly potent melanotropic peptides in the adrenal cortex of the rat. Acta Endocrinologica 113 396-402. 
Borelli MI, Morano MI, Estivariz FE \& Gagliardino JJ 1994 Glucose-induced secretion of ACTH-like products by rat pancreatic islets. Archives Internationales de Physiologie de Biochimie et de Biophysique 102 17-20.

Borelli MI, Estivariz FE \& Gagliardino JJ 1996 Evidence for the paracrine action of islet-derived corticotropin-like peptides on the regulation of insulin release. Metabolism 45 565-570.

Boston BA \& Cone RD 1996 Characterization of melanocortin receptor subtype expression in murine adipose tissues and in the 3T3-L1 cell line. Endocrinology 137 2043-2050.

Botelho LHP, Rothermel JD, Coombs RV \& Jastorff B 1988. cAMP analog antagonists of cAMP action. Methods in Enzymology 159 159-172.

Charmandari E, Matthews DR, Johnston A, Brook CG \& Hindmarsh PC 2002 Serum cortisol and 17-hydroxyprogesterone interrelation in classic 21-hydroxylase deficiency: is current replacement therapy satisfactory? Journal of Clinical Endocrinology and Metabolism $\mathbf{8 6}$ 4679-4685.

Chijiwa T, Mishima A, Hagiwara M, Sano M, Hayashi K, Inoue T, Naito K, Toshioka T \& Hidaka H 1990 Inhibition of forskolin-induced neurite outgrowth and protein phosphorylation by a newly synthesized selective inhibitor of cAMP-dependent protein kinase, $\mathrm{N}$-[2-(p-bromocinnamylamino)ethyl]-5isoquinolinesulfonamide (H-89), of PC12D pheochromocytoma cells. Journal of Biological Chemistry 265 5267-5272.

Curry DL \& Bennett LL 1973 Dynamics of insulin release by perfused rat pancreases: effects of hypophysectomy, growth hormone, adrenocorticotropic hormone, and hydrocortisone. Endocrinology 93 602-609.

Davies E, Kenyon CJ \& Fraser R 1985 The role of Ca2+ ions in the mechanism of ACTH stimulation of cortisol synthesis. Steroids $\mathbf{4 5}$ 551-560.

Estivariz FE, Morano MI, Carino M, Jackson S \& Lowry PJ 1988 Adrenal regeneration in the rat is mediated by mitogenic $\mathrm{N}$-terminal pro-opiomelanocortin peptides generated by changes in precursor processing in the anterior pituitary. Journal of Endocrinology 116 207-216.

Flores LE, Francini F \& Gagliardino JJ 1998 Modulatory effect of hormones on insulin secretion in vitro in the toad. Comparative Biochemistry and Physiology C-Pharmacology, Toxicolology, Endocrinology $12077-81$

Gagliardino JJ, Borelli MI, Boschero AC, Rojas E \& Atwater I 1995 Modulatory mechanism of ACTH on insulin secretion: effect on cytosolic $\mathrm{Ca}^{2+}$, membrane potential and $\mathrm{Ca}^{2+}$-ATPase activity. Archives of Physiology and Biochemistry 103 73-78.

Gagliardino JJ, Borelli MI, Estivariz F, Atwater I, Boschero C \& Rojas E 1997 Islet release of ACTH-like peptides and their modulatory effect on insulin secretion. Advances in Experimental Medicine and Biology 426 121-127.

Gallo-Payet N \& Payet MD 1989 Excitation-secretion coupling: involvement of potassium channels in ACTH-stimulated rat adrenocortical cells. Journal of Endocrinology 120 409-421.

Garren LD, Gill GN, Masui H \& Walton GM 1971 On the mechanism of action of ACTH. Recent Progress in Hormone Research 27 433-478.

Gao Z, Young RA, Trucco MM, Greene SR, Hewlett EL, Matchinsky FM \& Wolf BA 2002 Protein kinase A translocation and insulin secretion in pancreatic $\beta$-cells. Biochemical Journal 368 397-404.

Gey GO \& Gey MK 1936 The maintenance of human normal cells in continuous culture. Preliminary report: cultivation of mesoblastic tumours and normal cells and notes on method of cultivation. American Journal of Cancer 27 45-76.

Gomez E, Pritchard C \& Herbert TP 2002 cAMP-dependent protein kinase and $\mathrm{Ca}^{2+}$ influx through L-type voltage-gated $\mathrm{Ca}^{2+}$ channels mediate Raf-independent activation of Extracellular Regulated Kinase in response to Glucagon-like Peptide-1 in pancreatic cells. Journal of Biological Chemistry 277 48146-48151.
Gronda CM, Diaz GB, Rossi JP \& Gagliardino JJ 1992 Correlation between $\mathrm{Ca}^{2+}$-ATPase activity of rat islet cells and insulin secretion. Journal of Endocrinology 134 221-225.

Hadley ME \& Haskell-Luevano C 1999 The Proopiomelanocortin system. Annals of the New York Academy of Sciences 885 1-21.

Harper JP \& Brooker G 1975 Femtomole sensitive radioimmunoassay for cAMP and cyclic GMP after 2'O- acetylation by acetic anhydride aqueous solution. Journal of Cyclic Nucleotide Research 1 207-218.

Hauge-Evans AC, Squires PE, Persaud SJ \& Jones PM 1999 Pancreatic beta-cell-to-beta-cell interactions are required for integrated responses to nutrient stimuli: enhanced $\mathrm{Ca}^{2+}$ and insulin secretory responses of MIN6 pseudoislets. Diabetes 48 1402-1408.

Hughes SJ \& Ashcroft SJH 1992 cAMP, protein phosphorylation and insulin secretion. In: Nutrient Regulation of Insulin Secretion, pp 125-156. Ed PR Flatt. London: Portland Press.

Jones PM \& Persaud SJ 1998 Protein kinase, protein phosphorylation and the regulation of insulin secretion from pancreatic $\beta$-cells. Endocrine Reviews 19 429-461.

Jones PM, Salmon DMW \& Howell SL 1988 Protein phosphorylation in electrically permeabilised islets of Langerhans. Effects of $\mathrm{Ca}^{2+}$, cAMP, a phorbol ester and noradrenaline. Biochemical Journal 254 397-403.

Jones PM, Persaud SJ \& Howell SL 1989 Time-course of $\mathrm{Ca}^{2+}$-induced insulin secretion from perifused, electrically permeabilised islet of Langerhans: Effect of cAMP and a phorbol ester. Biochemical and Biophysical Research Communications 162 998-1003.

Kenyon CJ, Young J \& Fraser R 1985 Potassium fluxes in bovine adrenal cells during adrenocorticotropin stimulation. Endocrinology 116 2279-2285.

Kesper S, Rucha J, Neye H, Mazenot C \& Vershpol EJ 1999 $\mathrm{G} \alpha_{\mathrm{i} 2}$-mRNA and -protein regulation as a mechanism for heterologous sensitization and desensitization of insulin secretion. Cellular Signaling 11 759-768.

Kojima I, Kojima K \& Rasmussen H 1985a Characteristics of angiotensin II-, $\mathrm{K}^{+}$- and ACTH-induced $\mathrm{Ca}^{2+}$ influx in adrenal glomerulosa cells. Evidence that angiotensin II, $\mathrm{K}^{+}$, and ACTH may open a common $\mathrm{Ca}^{2+}$ channel. Journal of Biological Chemistry 260 9171-9176.

Kojima I, Kojima K \& Rasmussen H $1985 b$ Role of $\mathrm{Ca}^{2+}$ and cAMP in the action of adrenocorticotropin on aldosterone secretion. Journal of Biological Chemistry $2604248-4256$.

Kuo WN, Hodgins DS \& Kuo JF 1973 Adenylate cyclase in islets of Langerhans. Isolation of islets and regulation of adenylate cyclase activity by various hormones and agents. Journal of Biological Chemistry 248 2705-2711.

Larsson LI 1978 Distribution of ACTH-like immunoreactivity in rat brain and gastrointestinal tract. Histochemistry 55 225-233.

Lebovitz HE \& Pooler K 1967 ACTH-mediated insulin secretion: effect of aminophylline. Endocrinology 81 558-564.

Lebovitz HE, Bryant K \& Frohman LA 1965 Acute effects of corticotropin and related peptides on carbohydrate and lipid metabolism. Annals of the New York Academy of Sciences 131 274-287.

Lebovitz HE, Genuth S \& Pooler K 1966 Relationships between the structure and biological activities of corticotropin and related peptides: hyperglycemic action of $\mathrm{N}$-acetylated corticotropin related peptides. Endocrinology 79 635-642.

London NJ, Lake SP, Wilson J, Bassett D, Toomey P, Bell PR, James RF \& Slapak M 1990 A simple but effective method for the controlled collagenase digestion of the human pancreas. Transplantation Proceedings 22 791-792.

London NJ, Swift SM \& Clayton HA 1998 Isolation, culture and functional evaluation of islets of Langerhans. Diabetes and Metabolism $24200-207$. 
Malaisse WJ, Malaisse-Lagae F \& Mayhew D 1967 A possible role for the adenyl cyclase system in insulin secretion. Journal of Clinical Investigation 46 1724-1734.

Merke DP, Bornstein SR, Avila NA \& Chrousos GP 2002 NIH conference. Future directions in the study and management of congenital adrenal hyperplasia due to 21-hydroxylase deficiency. Annals of Internal Medicine 136 320-334.

Mountjoy KG, Robbins LS, Mortrud MT \& Cone RD 1992 The cloning of a family of genes that encode the melanocortin receptors. Science 257 1248-1251.

Newell-Price J, Trainer P, Besser M \& Grossman A 1998 The diagnosis and differential diagnosis of Cushing's syndrome and pseudo-Cushing's states. Endocrine Reviews 19 647-672.

O’Shaughnessy PJ, Fleming LM, Jackson G, Hochgeschwender U, Reed P \& Baker PJ 2003 Adrenocorticotropic hormone directly stimulates testosterone production by the fetal and neonatal mouse testis. Endocrinology 144 3279-3284.

Persaud SJ, Jones PM \& Howell SL 1990 Glucose-stimulated insulin secretion is not dependent on activation of protein kinase A. Biochemical and Biophysical Research Communications 173 833-839.

Persaud SJ, Asare-Anane H \& Jones PM 2002 Insulin receptor activation inhibits insulin secretion from human islets of Langerhans. FEBS Letters $\mathbf{5 1 0}$ 225-228.

Pipeleers DG 1987 The biosociology of pancreatic B-cells. Diabetologia 32 277-290.

Putti R, Buono S \& Ottaviani E 1999 PP/PYY cells from endocrine pancreas of the scincid lizard Eumeces inexpectatus synthesize ACTHand $\alpha-\mathrm{MSH}$-like molecules. General and Comparative Endocrinology 116 153-163.

Roderigo-Milne HM, Hauge-Evans AC, Persaud SJ \& Jones PM 2002 Differential expression of insulin genes 1 and 2 in MIN6 cells and pseudoislets. Biochemical and Biophysical Research Communications $296589-595$.

Sanchez-Franco F, Patel YC \& Reichlin S 1981 Immunoreactive adrenocorticotropin in the gastrointestinal tract and pancreatic islets of the rat. Endocrinology 108 2235-2238.
Schiebinger RJ, Braley LM, Menachery A \& Williams GH 1986 Unique $\mathrm{Ca} 2+$ dependencies of the activating mechanism of the early and late aldosterone biosynthetic pathways in the rat. Journal of Endocrinology 110 315-325.

Schioth HB, Chhajlani V, Muceniece R, Klusa V \& Wikberg JE 1996 Major pharmacological distinction of the ACTH receptor from other melanocortin receptors. Life Sciences 59 797-801.

Slominski A, Ermak G \& Mihm M 1996 ACTH receptor, CYP11A1, CYP17 and CYP21A2 genes are expressed in skin. Journal of Clinical Endocrinology and Metabolism 81 2746-2749.

Solomon S 1999 POMC-derived peptides and their biological action. Annals of the New York Academy of Sciences 885 22-40.

Squires PE, James RFL, London NMJ \& Dunne MJ 1994 ATP-induced intracellular $\mathrm{Ca}^{2+}$ signals in isolated human insulin-secreting cells. Pflugers Archiv 427 181-183.

Sussman KE \& Vaughan GD 1967 Insulin release after ACTH, glucagon and adenosine- $3^{\prime}, 5^{\prime}$-phosphate (cAMP) in the perifused isolated rat pancreas. Diabetes 16 449-454.

Verspohl E J \& Wienecke A 1998 The role of protein kinase C in the desensitization of rat pancreatic islets to cholinergic stimulation. Journal of Endocrinology 159 287-295.

Vinson GP, Whitehouse BJ \& Hinson JP 1992 In The Adrenal Cortex, ch 3, pp 65-116. Englewood Cliffs: Prentice Hall.

Xia Y \& Wikberg JE 1996 Localization of ACTH receptor mRNA by in situ hybridization in mouse adrenal gland. Cell and Tissue Research 286 63-68.

Received in final form 9 September 2003

Accepted 25 September 2003

Made available online as an

Accepted Preprint 10 October 2003 